\title{
New calcium alkoxides for consolidation of carbonate rocks. Influence of precursors' characteristics on morphology, crystalline phase and consolidation effects
}

\author{
Franco Ossola, Patrizia Tomasin,* Chiara De Zorzi, Naida El Habra, \\ Matteo Chiurato and Monica Favaro
}

Received (in Montpellier, France) 9th August 2012, Accepted 8th October 2012

DOI: $10.1039 / \mathbf{c} 2$ ju40708f

New ambient temperature liquid calcium alkoxides, $\left[\mathrm{Ca}\left(\mathrm{O}\left(\mathrm{CH}_{2} \mathrm{CH}_{2} \mathrm{O}\right)_{3} \mathrm{CH}_{3}\right)_{2}\right](\mathbf{1})$ and

$\left[\mathrm{Ca}\left(\mathrm{O}\left(\mathrm{CH}_{2} \mathrm{CH}_{2} \mathrm{O}\right)_{3} \mathrm{CH}_{2} \mathrm{CH}_{3}\right)_{2}\right]$ (2), together with $\left[\mathrm{Ca}\left(\mathrm{OCH}_{2} \mathrm{C}\left(\mathrm{CH}_{3}\right)_{3}\right)_{2}\right](3)$, were synthesised by reaction of ammonia-activated calcium with the appropriate alcohol. Their potentiality as stone consolidant products was investigated and compared with those of other alkoxides:

$\left[\mathrm{Ca}\left(\mathrm{OCH}_{2} \mathrm{CH}_{3}\right)_{2}\left(\mathrm{CH}_{3} \mathrm{CH}_{2} \mathrm{OH}\right)_{4}\right](\mathbf{4}),\left[\mathrm{Ca}\left(\mathrm{OCH}_{3}\right)_{2}\right](\mathbf{5}),\left[\left\{\mathrm{Ca}\left(\mathrm{OCH}_{2} \mathrm{CH}_{2} \mathrm{OCH}_{3}\right)_{2}\right\}_{9}\right](\mathbf{6})$, already

described in the literature. Reaction of 1-3 with the atmosphere was studied, final products

analysed and kinetic pathways investigated. The reaction produces $\mathrm{CaCO}_{3}$ and the vaterite/calcite

ratios observed in the coatings generated from isopropyl alcohol solutions of 1-6 were found to considerably vary with the alkoxide precursor, which has a strong influence also on the

morphology of the produced films. Furthermore, their efficiency as stone consolidants was tested

by ultrasound measurements.

\section{Introduction}

Recently, we reported on the potential use of calcium alkoxides as an alternative class of compounds for consolidation of carbonate rocks, most of them used for historical artifacts and buildings. ${ }^{1}$ We evaluated the possibility to use, as a consolidating agent, the calcium carbonate produced from hydrolysis-carbonation of calcium alkoxides, in a similar way as carbonation of calcium hydroxide leads to hardening of deteriorated limestone, lime mortars and wall paintings; in fact, the traditional lime method, whose main problem is the very low solubility of $\mathrm{Ca}(\mathrm{OH})_{2}$, has recently been reconsidered with the innovative use of nanolime dispersions. ${ }^{2,3}$ The calcium alkoxide, dissolved in an organic solvent, penetrates within the stone pore network where it reacts with moisture and carbon dioxide of the atmosphere generating in situ calcium carbonate, which fills the micro-fissures and binds the stone fragments together. Up to now, their very low solubility has hampered their successful application as alternative consolidation products to available commercial products, because the low amount of $\mathrm{CaCO}_{3}$ deposited in each application would consequently determine too many disadvantageous repetitions of the treatment. On the other hand, insolubility, together with low volatility, are general characteristics of group 2 metal alkoxides with conventional monodentate alkoxide ligands,

Istituto di Chimica Inorganica e delle Superfici, C.N.R., Corso Stati Uniti 4,35127 Padova, Italy.E-mail: patrizia.tomasin@cnr.it due to their tendency to oligomerise, ${ }^{4-6}$ which minimize their utilization also in other fields of application, such as sol-gel and chemical vapour deposition (CVD) ${ }^{7,8}$

With the aim to increase solubility, starting alcohols with increased steric hindrance (2,2-dimethyl-1-propanol) and additional coordinating atoms (2-methoxyethanol, two oligoethers) were chosen for the synthesis of calcium alkoxides. Here we describe the new complexes synthesised with the ammonia method, ${ }^{9} \quad\left[\mathrm{Ca}\left(\mathrm{O}\left(\mathrm{CH}_{2} \mathrm{CH}_{2} \mathrm{O}\right)_{3} \mathrm{CH}_{3}\right)_{2}\right] \quad$ (1) and $\left[\mathrm{Ca}\left(\mathrm{O}\left(\mathrm{CH}_{2} \mathrm{CH}_{2} \mathrm{O}\right)_{3} \mathrm{CH}_{2} \mathrm{CH}_{3}\right)_{2}\right]$ (2), the first calcium alkoxides in liquid form. $\left[\mathrm{Ca}\left(\mathrm{OCH}_{2} \mathrm{C}\left(\mathrm{CH}_{3}\right)_{3}\right)_{2}\right](3)$, already known, ${ }^{6}$ was newly synthesised with the same method.

Once fully characterized, they were applied on glass frits and slides and the influence of precursors' characteristics on the reaction with the atmosphere, on the morphology and phase of the resulting calcium carbonate coatings is discussed.

Furthermore, ultrasonic velocity measurements were used to evaluate the consolidation efficacy after their application on model samples of Carrara marble, metamorphic carbonate rock. In fact, the velocity of the compressive wave $\left(\mathrm{m} \mathrm{s}^{-1}\right)$ is one of the non-destructive tests more widely used to assess strengthening effects of stone treatments; the velocity of the ultrasonic wave mainly depends on the porosity and the $E$-modulus of the material. Since consolidants are supposed to change stone porosity and mechanical properties, ultrasonic velocity is usually considered a good diagnostic tool to trace these changes. ${ }^{10,11}$

Their decomposition behaviour and stone consolidation efficiency, after their application on marble specimens, were 
compared with those of other calcium alkoxides: $\left[\mathrm{Ca}\left(\mathrm{OCH}_{2} \mathrm{CH}_{3}\right)_{2}\left(\mathrm{CH}_{3} \mathrm{CH}_{2} \mathrm{OH}\right)_{4}\right](4),\left[\mathrm{Ca}\left(\mathrm{OCH}_{3}\right)_{2}\right](5), \quad[\{\mathrm{Ca}$ $\left.\left.\left(\mathrm{OCH}_{2} \mathrm{CH}_{2} \mathrm{OCH}_{3}\right)_{2}\right\}_{9}\right](6){ }^{12}$

\section{Results and discussion}

\section{Synthesis of calcium alkoxides}

Synthesis of calcium alkoxides 4-6 involved direct reaction of metallic calcium with the proper alcohol, whereas compounds 1-3 were prepared by using ammonia-activated calcium ${ }^{9}$ in high yield and purity. It has to be noted that compound $\mathbf{3}$ was newly synthesised with this method.

In the synthesis of $\mathbf{1}$ and $\mathbf{2}$ the corresponding oligoether alcohols were added to elemental calcium in slight defect with respect to the stoichiometric amount, in order to avoid their possible coordination (as unreacted reagents) to the calcium metallic centre and unreacted calcium was filtered at the end of the reactions. Differently from the features usually presented by calcium alkoxides, $\mathbf{1}$ and $\mathbf{2}$ showed a peculiar room temperature dense liquid state and were highly soluble in organic solvents.

The proposed formulas are made on the basis of elemental analysis and NMR and FT-IR spectra. Since the main goal of this paper was to verify the behaviour in marble consolidation, no in depth structural analyses were carried out.

The interpretation of the ${ }^{1} \mathrm{H}$ and ${ }^{13} \mathrm{C}$ NMR spectra of 2 in toluene- $\mathrm{d}_{8}$ was not straightforward; bidimensional experiments 2D COSY and HMQC were carried out to attempt a correct attribution of the signals, most of which were overlapping.

It was possible to unambiguously identify the triplet related to $\mathrm{OCH}_{2} \mathrm{CH}_{3}$ at $1.14 \mathrm{ppm}(6 \mathrm{H})$, the quartet related to $\mathrm{OCH}_{2} \mathrm{CH}_{3}$ at $3.37 \mathrm{ppm}(4 \mathrm{H})$, the triplet assigned to $\mathrm{CH}_{2} \mathrm{OCH}_{2} \mathrm{CH}_{3}$ at $3.49 \mathrm{ppm}(4 \mathrm{H})$ and the two broad signals of the $\mathrm{CH}_{2} \mathrm{CH}_{2} \mathrm{OCa}$ protons at $3.77(\mathrm{~s}, 4 \mathrm{H})$ and $4.20 \mathrm{ppm}(\mathrm{s}$, $4 \mathrm{H})$. The assignment of the remaining peaks at $3.60(\mathrm{sb}, 4 \mathrm{H})$, $3.69(\mathrm{sb}, 4 \mathrm{H})$ and $3.81 \mathrm{ppm}(\mathrm{sb}, 4 \mathrm{H})$, due to the other $\mathrm{CH}_{2} \mathrm{O}$ protons, is less certain. Through the correlations in the heteronuclear bidimensional spectrum HMQC, the attribution of the ${ }^{13} \mathrm{C}$ resonances was also possible (see the Experimental section).

In the ${ }^{1} \mathrm{H}$ spectrum of $\mathbf{1}\left(\mathrm{C}_{6} \mathrm{D}_{6}\right)$, peaks were assigned on the basis of chemical shift, integral values and by comparison with the spectra of 2 . The methoxy protons singlet at $3.20 \mathrm{ppm}(6 \mathrm{H})$ and the $3.44 \mathrm{ppm}$ broad triplet of $\mathrm{CH}_{2} \mathrm{OCH}_{3}(4 \mathrm{H})$ match well with the corresponding signals found for the analogous barium complex $\left[\mathrm{Ba}\left[\mathrm{O}\left(\mathrm{CH}_{2} \mathrm{CH}_{2} \mathrm{O}\right)_{3} \mathrm{CH}_{3}\right]_{2}\right],{ }^{13}$ whereas the unassignable multiplet between 3.68 and $4.10 \mathrm{ppm}$ and the broad singlets at $3.61\left(\mathrm{CH}_{2} \mathrm{O}, 4 \mathrm{H}\right)$ and $4.37 \mathrm{ppm}$ $\left(\mathrm{CH}_{2} \mathrm{CH}_{2} \mathrm{OCa}, 4 \mathrm{H}\right)$ present a slight shift to higher frequencies with respect to the barium congener. On the basis of these NMR analogies, a monomeric structure, similar to that found for the Ba complex, can be proposed for $\mathbf{1}$, the downfield shift probably due to the shorter ionic radius of $\mathrm{Ca}$ with respect to $\mathrm{Ba}$, determining a slightly different rearrangement around the metal.

\section{Calcium alkoxides reactions with the atmosphere: $\mathrm{CaCO}_{3}$ deposition}

Reactions of complexes 1-6 with the atmosphere have been studied, final products analysed and kinetic pathways investigated.

A preliminary evaluation of stability of alkoxides in $i-\mathrm{PrOH}$ was run, resulting in a good stability and excluding alcohol interchange reactions.

Exposure of isopropyl alcohol solutions to the atmosphere gave rise to spontaneous reactions of the complexes with air and deposition of white coatings on the surfaces of the vessels.

Reflectance IR measurements have been performed on a gold surface after deposition of a drop of alcoholic solution of the alkoxides. IR spectra were collected at different times until complete conversion of compounds to $\mathrm{CaCO}_{3}$. As an example, spectra of compound $\mathbf{1}$ collected at different times are reported in Fig. 1. In addition to the characteristic signals of the metal alkoxides, an absorption at $1640-1655 \mathrm{~cm}^{-1}$ has been readily observed for all complexes, corresponding to the $\mathrm{CH}_{3} \mathrm{OCO}_{2}$

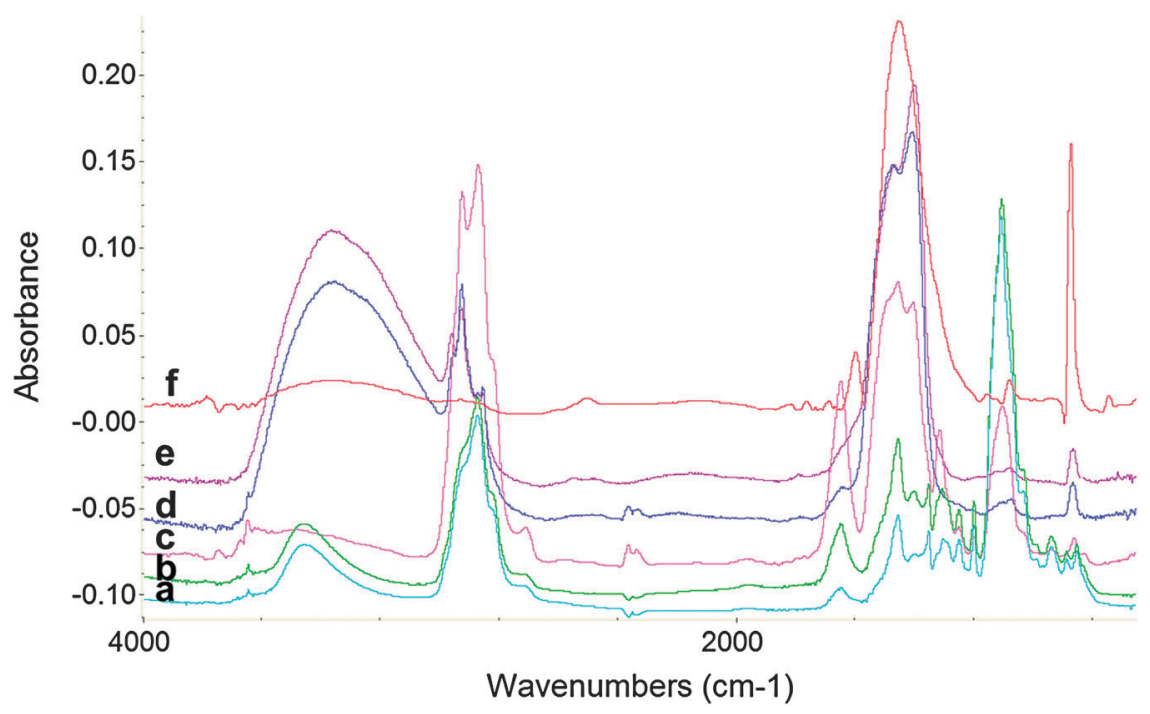

Fig. 1 FT-IR spectra of the products resulting from the reaction of 1 with the atmosphere. Time of collection: (a) 0; (b) $5 \mathrm{~min}$; (c) $30 \mathrm{~min}$; (d) 6 h; (e) 4 days (f) six months. 
group formed by insertion of $\mathrm{CO}_{2}$ in the $\mathrm{Ca}-\mathrm{O}$ bond of the calcium alkoxides and producing the corresponding calcium alkyl carbonates. ${ }^{114}$ This insertion process is immediate for compounds $\mathbf{4}$ and $\mathbf{5}$, giving rise to a strong band centred at $1653 \mathrm{~cm}^{-1}\left(1634 \mathrm{~cm}^{-1}\right.$ for 5), while it is much slower for the other complexes. The different kinetic stability is probably due to the reduced accessibility of the more sterically hindered central calcium atom in $\mathbf{1}, \mathbf{2}$, and $\mathbf{3}$ with respect to $\mathbf{4}$ and $\mathbf{5}$. Alkyl carbonate absorptions decrease until disappearance in about 6 hours, while new signals at $1390-1450$ and $873 \mathrm{~cm}^{-1}$, characteristic of $\mathrm{CaCO}_{3}$, appear and rise. These absorption patterns indicate that reactions of 1-4 with the atmosphere take place mainly through $\mathrm{CO}_{2}$ insertion into the $\mathrm{Ca}-\mathrm{O}$ bond of the calcium alkoxides with formation of alkylcarbonate derivatives, subsequently transformed into $\mathrm{CaCO}_{3}$. Nevertheless, a second kinetic pathway is suggested for $\mathbf{1 , 4}$ and $\mathbf{6}$, as already described for $5 .{ }^{1}$ In fact, the appearance of a sharp absorption at $3645 \mathrm{~cm}^{-1}$, typical of $\mathrm{OH}$ stretching, suggests that an hydrolysis process occurs with formation of $\mathrm{Ca}(\mathrm{OH})_{2}$, which is successively carbonated to $\mathrm{CaCO}_{3}$ through $\mathrm{CO}_{2}$ insertion into the $\mathrm{Ca}-\mathrm{O}$ bond. This process generates variously coordinated bicarbonate groups, as evidenced by signals at 1598, 1475-1468 and 1395-1400 $\mathrm{cm}^{-1}$, overlapping $\mathrm{CaCO}_{3}$ absorption bands. The hydrolysis process is competitive with one leading to insertion of $\mathrm{CO}_{2}$ and it was observed in some compounds rather than in others independently from their structure. It appears to be influenced mostly by the humidity content in the atmosphere.

Morphological observations were performed on the calcium carbonate films produced from reaction with the atmosphere of complexes 1-6. With a view to a possible utilization as stone consolidant products, porous glassy frits, simulating the deteriorated stone, were impregnated with isopropyl alcohol solutions of complexes 1-4, $\mathbf{6}$ as described in the Experimental section and observations were carried out on the coatings formed inside the frits. Coatings were homogeneously deposited with good adhesion on the grains surface of the frit inside its pore network. They appear to be built up by aggregation of particles with nanoscale dimensions in one or more directions. As shown in Fig. 2 while $\mathbf{1}$ and $\mathbf{5}$ (deposited from solutions/dispersions with different solvents ${ }^{1}$ produce homogeneous coatings of round and platelet-like crystallites, 2 and $\mathbf{6}$ exhibit, respectively, isolated clusters of crystallization grains and finely dispersed particles; the coating formed after carbonation of $\mathbf{3}$ exhibits a fine-grained surface morphology, while the film generated from $\mathbf{4}$ consists of an agglomeration of spherical particles.

Microstructure of these coatings has been investigated by XRD and the obtained patterns are reported in Fig. 3. All the deposits from 1-5 were polycrystalline without preferential orientation, as shown by the analysis relative intensities of reflection, even if amorphous phases cannot be excluded.

The deposits obtained from $\mathbf{1}, \mathbf{3}$ and $\mathbf{4}$ clearly showed the co-presence of carbonatic phases $\left(\mathrm{CaCO}_{3}\right)$, such as vaterite with hexagonal structure (ICDD: 01-072-0506) and calcite with rhombohedral structure (ICDD: 01-086-2341). Nevertheless, the XRD pattern of the deposit obtained from 4 highlighted also the presence of portlandite (i.e. calcium hydroxide $\mathrm{Ca}(\mathrm{OH})_{2}$ ) with hexagonal structure (ICDD:

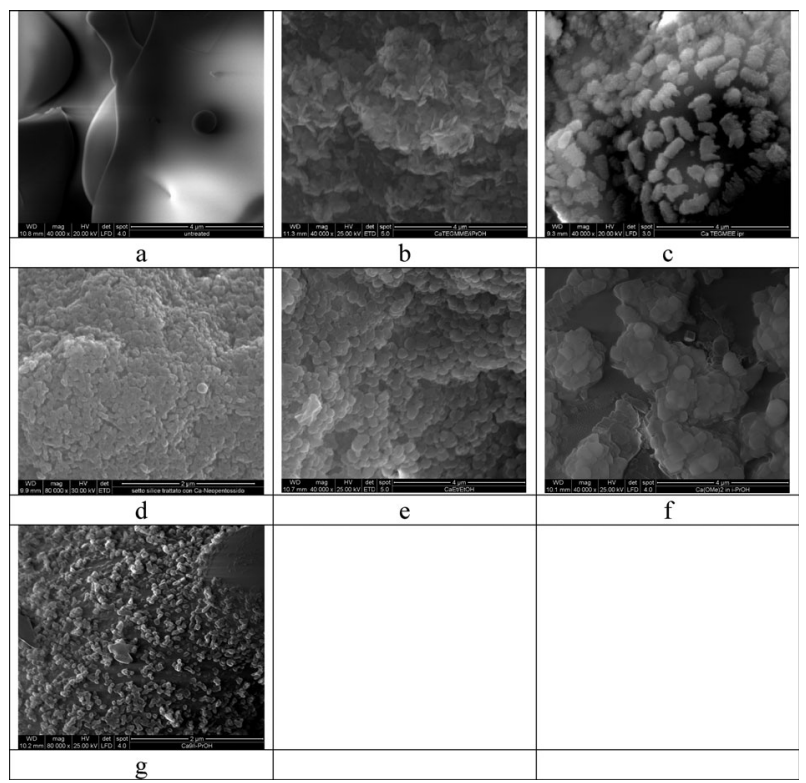

Fig. 2 Secondary electron images collected from (a) the untreated surface and from the coatings obtained from isopropyl alcohol solutions of (b) 1, (c) 2, (d) 3, (e) 4, (f) 5 and (g) 6. Magnification: 40.000× $(\mathrm{a}, \mathrm{b}, \mathrm{c}, \mathrm{e}, \mathrm{f}), 80.000 \times(\mathrm{d}, \mathrm{g})$.

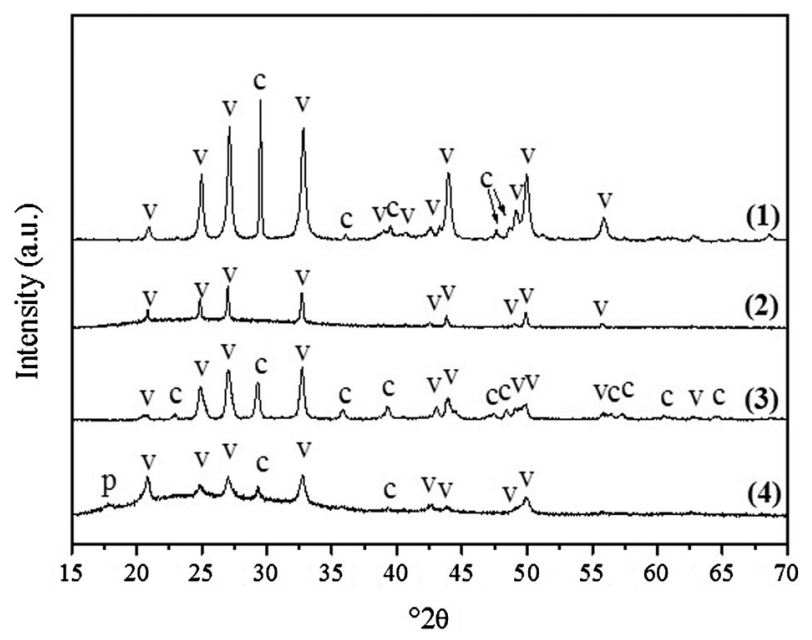

Fig. 3 XRD patterns of the coatings obtained from isopropyl alcohol solutions of complexes 1-4 (with $\mathrm{p}=$ portlandite, $\mathrm{v}=$ vaterite, $\mathrm{c}=$ calcite).

01-084-1276) as the minority phase, as indicated by the main $\mathrm{Ca}(\mathrm{OH})_{2}$ reflection at $2 \theta=17.8^{\circ}$ corresponding to the (001) Bragg reflection. It is noteworthy that the deposit obtained from $\mathbf{2}$ is composed of vaterite as the only crystalline phase. A semi quantitative estimation (RIR method) of the different phases, present in the analysed samples, is reported in Table 1 , which clearly shows vaterite is the main carbonatic phase. The vaterite prevalence among other phases can be ascribed to the employed solvents: alcohols like ethanol, isopropanol and diethylene glycol actually prevent the transformation of vaterite aggregates to calcite by influencing the surface charge of vaterite crystals. ${ }^{15,16}$ As previously reported ${ }^{1}$ depending on the solvent/dispersion agent and on 
Table 1 Semiquantitative estimation (RIR method) of the phases vaterite (hexagonal), calcite (rhombohedral) and portlandite (hexagonal) identified in the deposits analysed by XRD

\begin{tabular}{lll}
\hline Calcium alkoxide & Phase & $\begin{array}{l}\text { Semiquantitative } \\
(\%)\end{array}$ \\
\hline$\left[\mathrm{Ca}\left(\mathrm{O}\left(\mathrm{CH}_{2} \mathrm{CH}_{2} \mathrm{O}\right)_{3} \mathrm{CH}_{3}\right)_{2}\right](\mathbf{1})$ & Vaterite & 86 \\
{$\left[\mathrm{Ca}\left(\mathrm{O}\left(\mathrm{CH}_{2} \mathrm{CH}_{2} \mathrm{O}\right)_{3} \mathrm{CH}_{2} \mathrm{CH}_{3}\right)_{2}\right](\mathbf{2})$} & Calcite & 14 \\
$\left.\left[\mathrm{Ca}\left(\mathrm{OCH}_{2} \mathrm{C}_{(\mathrm{CH}}\right)_{3}\right)_{2}\right](\mathbf{3})$ & Vaterite & 100 \\
& Caterite & 66 \\
{$\left[\mathrm{Ca}\left(\mathrm{OCH}_{2} \mathrm{CH}_{3}\right)_{2}\left(\mathrm{CH}_{3} \mathrm{CH}_{2} \mathrm{OH}\right)_{4}\right]$} & Vaterite & 34 \\
$(4)$ & Calcite & 98 \\
& Portlandite & 3 \\
\hline
\end{tabular}

the substrate, the vaterite/calcite ratio in the deposit of $\mathbf{5}$ can vary considerably. Compound $\mathbf{6}$ does not follow a defined decomposition pathway; different preparation and samples of the compound, after atmospheric exposure, gave different crystallographic results, ranging from amorphous deposits to crystalline systems with vaterite only, vaterite-calcite mixtures, vaterite-portlandite mixtures, without great reproducibility. Studies are currently in progress to determine the parameters influencing the final product.

In fact, the decomposition processes, carried out under environmental conditions, might be influenced by the different thermo-hygrometric conditions thus leading to the presence of portlandite and the conversion of vaterite to calcite. This could confirm what was already observed for $\mathbf{5}$, where the crystalline phases of the final $\mathrm{CaCO}_{3}$ deposit varied in accordance with different deposition conditions. ${ }^{1}$

Elemental analyses were also carried out on these coatings. The results were: film obtained from $1 \mathrm{C} 13.87, \mathrm{H} 0.00 \%$; from 2 C 13.08 , H 0.15\%; from 3 C 13.50, H $0.00 \%$; from $4 \mathrm{C}$ $11.77, \mathrm{H} 0.21 \%$; calcd for $\mathrm{CaCO}_{3}$ : C $12.00, \mathrm{H} 0.00 \%$. Results are essentially in agreement with $\mathrm{CaCO}_{3}$ formulation and with the XRD measurements. Higher percentage values found for $\mathrm{C}$ in 1-3 suggest that small organic fractions (most likely the high boiling point alcohols) could remain trapped in the $\mathrm{CaCO}_{3}$ coatings.

\section{Evaluation of Ca alkoxides as stone consolidants}

Products applied as consolidants on disaggregated stone should improve substrate intergranular cohesion, thus reducing the porosity and restoring mechanical properties. Ultrasound velocity measurements, related to these parameters, were performed to evaluate consolidation efficacy.

As described in the Experimental section, marble specimens were treated three times for two hours with alkoxides 1-6 in isopropyl alcohol (Fig. 4). It was observed that during each imbibition, the clear solutions suddenly turned cloudy for alkoxides $(\mathbf{3}, \mathbf{5})$ and a fine precipitate deposited on the bottom of the vessel. This behaviour was not evidenced in 1, 2, 4 and 6 , whose solutions remained stable at least for 3-4 hours of exposure. The identity of the precipitate $\left(\mathrm{CaCO}_{3}\right)$ was confirmed by IR measurements.

Three weeks after the treatment, the weight and ultrasonic velocity changes were determined (Table 2). For 1, 2, 4 and 6 weight increases have been observed; while for $\mathrm{Ca}(\mathrm{OH})_{2}, \mathbf{3}, \mathbf{5}$ the increase is negligible. This can be related to the different solubility and reactivity with the atmosphere, depending on the different coordinative saturation of the calcium centre. This explains the formation of $\mathrm{CaCO}_{3}$ precipitates for $\mathbf{3}$ and $\mathbf{5}$ and, above all, the observations of ultrasonic velocity variation after treatment: $\mathrm{Ca}(\mathrm{OH})_{2}$, compounds $\mathbf{3}$ and $\mathbf{5}$ increased the velocity by $5.5,5.7$ and $3.7 \%$, respectively, in comparison with the untreated stone, while compounds, 1, 2, 4, 6 induced a positive variation that range from 9.7 to $28 \%$.

According to the obtained results, it is confirmed that the employment of more sterically hindered and/or electron donor atom containing ligands produces alkoxides with a higher solubility and stability. This allows a slower decomposition of the product, so a longer staying inside the stone pore network where the formation of $\mathrm{CaCO}_{3}$ can take place. This

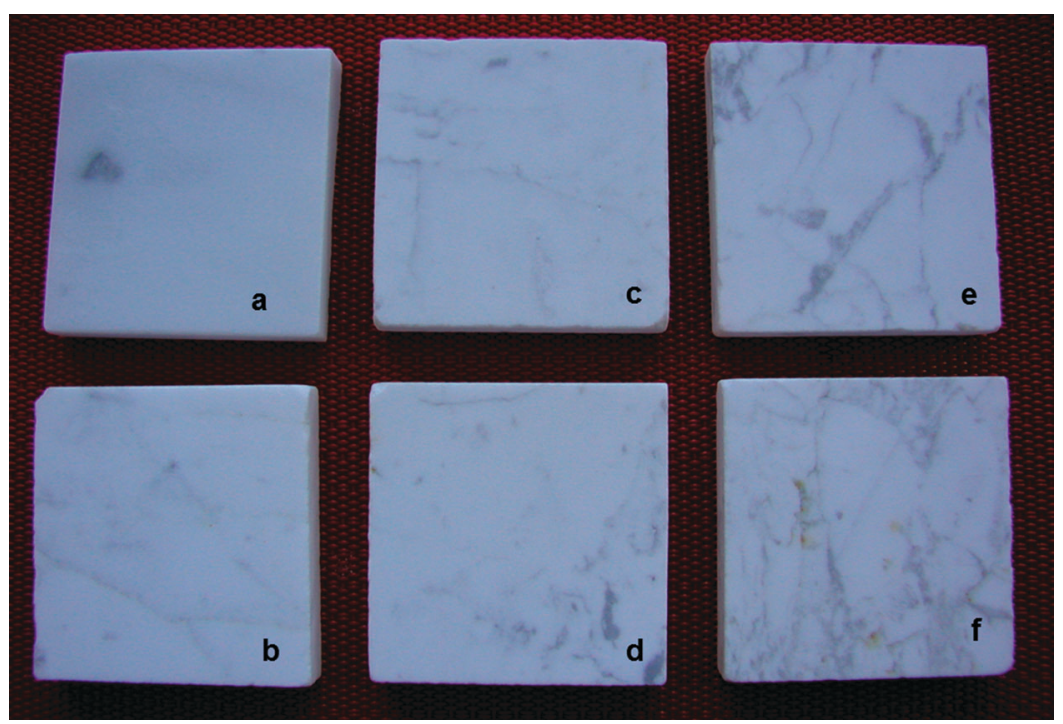

Fig. 4 Images collected from Carrara marble samples sized $5 \times 5 \times 1 \mathrm{~cm}^{3}$ : (a) untreated, un-aged, (b) untreated aged, (c) aged and treated with $\mathbf{5}$, (d) aged and treated with $\mathbf{4}$, (e) aged and treated with 1, (f) aged and treated with $\mathbf{2}$. The reddish-orange spots on (d) and (f) are due to oxidation of impurities of pyrite contained in the marble. 
Table 2 Herein are reported the products applied on marble specimens, their molecular weights, the weight changes induced by the application, the ultrasonic velocities measured before (bt) and after treatment (at) and the corresponding calculated percentage variation

\begin{tabular}{|c|c|c|c|c|c|}
\hline Code & Applied product & Weight increase (mg) & US v-bt $\left(\mathrm{m} \mathrm{s}^{-1}\right)$ & US v-at $\left(\mathrm{m} \mathrm{s}^{-1}\right)$ & US v variation $(\%)$ \\
\hline & Untreated marble & - & $1307 \quad 190$ & $1308 \quad 87$ & 0.1 \\
\hline & $\mathrm{Ca}(\mathrm{OH})_{2}$ & $\begin{array}{ll}0.6 & 0.2\end{array}$ & 122657 & 1294141 & 5.5 \\
\hline 5 & {$\left[\mathrm{Ca}(\mathrm{MeO})_{2}\right]$} & $\begin{array}{ll}0.4 & 0.2\end{array}$ & $1191 \quad 10$ & 1235151 & 3.7 \\
\hline 3 & {$\left[\mathrm{Ca}(\mathrm{NpO})_{2}\right]$} & $\begin{array}{ll}0.6 & 0.2\end{array}$ & $975 \quad 68$ & 103129 & 5.7 \\
\hline 4 & {$\left[\mathrm{Ca}(\mathrm{EtO})_{2} \cdot 4 \mathrm{EtOH}\right]$} & $\begin{array}{ll}10.7 & 0.7\end{array}$ & 100311 & $1095 \quad 35$ & 9.3 \\
\hline 6 & {$\left[\mathrm{Ca}_{9}(\mathrm{MeOEtO})_{18}\right]$} & $\begin{array}{lll}18.3 & 0.9\end{array}$ & $958 \quad 12$ & 106131 & 10.8 \\
\hline 1 & {$\left[\mathrm{Ca}(\mathrm{TEGMME})_{2}\right]$} & $25.7 \quad 3.4$ & 93328 & $1070 \quad 0.0$ & 14.7 \\
\hline 2 & {$\left[\mathrm{Ca}(\mathrm{TEGMEE})_{2}\right.$} & $\begin{array}{ll}12.9 & 1.3\end{array}$ & $886 \quad 42$ & 113436 & 28.0 \\
\hline
\end{tabular}

determines a better consolidating efficacy as evidenced by the increase in US measurements.

\section{Conclusions}

With the aim of finding new products for the re-aggregation of carbonate stone, new calcium alkoxides were synthesised and their properties compared with already known homologues.

It has to be noted that the first liquid calcium alkoxides were synthesised and they were found to be very soluble in most organic solvents.

Their decomposition pathways and the final formed $\mathrm{CaCO}_{3}$ coating were evaluated respectively by FT-IR, and by FEG-ESEM and XRD; the complexes turn out to be possible candidates for the consolidation purpose. The compounds are stable in organic solvents and give a low interchange reaction with $i$-PrOH. For this reason calcium alkoxides seem to be promising as consolidating agents and this is confirmed by the good results in US variation for the most soluble of them. The consolidation properties seem to be related to solubility and stability of the alkoxides in solution, these depending on the properties of the used ligand.

Further studies are needed to ascertain the effects of the length of the chain and of substituents or heteroatoms in the chain on the oligomerisation degree and on the solubility of the compounds. A better evaluation of the stability in different solvents will be essential for storage and application of the compounds in conservation.

Moreover, studies will be carried out to elucidate the influence of the thermo-hygrometric parameters on the kinetic pathway of alkoxide decomposition and on the final structure of the coating.

All the previous aspects are currently under investigation within the European Project NANOMATCH. ${ }^{17}$

\section{Experimental}

\section{General instrumentation}

NMR spectra were recorded on a Bruker AMX300 spectrometer, equipped with a $5 \mathrm{~mm}$ broad-band multinuclear probe, operating at a frequency of $300.13 \mathrm{MHz}$ for ${ }^{1} \mathrm{H}$ and $75.43 \mathrm{MHz}$ for ${ }^{13} \mathrm{C}$. The samples were dissolved in the appropriate deuterated solvents that were also used as internal references.

Elemental analyses were performed with a Fisons EA 1108 (CHNS-O version) elemental analyser. The samples were prepared by scratching the coatings from glass slides and vessels.
A Nicolet microscope connected to a Nicolet 560 FT-IR system, equipped with a MCT (Mercury Cadmium Telluride) detector, has been used for spectra collection of calcium alkoxides and related conversion products. Investigated micro areas were about $50 \times 50 \mu^{2}$ of size. IR spectra were recorded in reflectance mode in the $4000-650 \mathrm{~cm}^{-1}$ range, with a resolution of $4 \mathrm{~cm}^{-1}$. Recorded spectra have been expressed by absorbance units and baseline corrected.

The microstructure characterization was carried out by X-ray diffraction (XRD) measurements by using a Philips PW 3020 powder diffractometer with a Bragg-Brentano $\theta-2 \theta$ geometry. The radiation used was the $\mathrm{Cu} \mathrm{K} \alpha$ $(\lambda=1.54056 \AA, 40 \mathrm{kV}, 30 \mathrm{~mA})$. All the patterns were collected in the $15^{\circ}-70^{\circ} 2 \theta$ range and peak positions were determined with a statistical error $\mathrm{d}(2 \theta)=0.02^{\circ}$. Phase identification was performed with the support of standard patterns reported in 2002 ICDD database. The semi-quantitative estimation of the different phases present in the single samples has been obtained by the Reference Intensity Ratio (RIR) method. ${ }^{18}$

Observations of the inorganic coatings deposited on glassy substrates have been performed by using a Fei Quanta 200 FEG-ESEM instrument to evaluate their morphology and the distribution inside the pore network. The semi-quantitative elemental compositions were obtained using an Energy Dispersive X-ray Spectrometer EDAX Genesys, using an accelerating voltage of $20 \mathrm{keV}$. The samples were analysed uncoated in low vacuum mode.

Weight difference was determined using a SCALTEC SBC22 balance $(0.00001 \mathrm{~g}$ sensitivity).

The ultrasonic portable instrument employed for the measurements is a USG 20 (Geotron Elektronik, Germany), operated with a point-shaped $46 \mathrm{kHz}$-vibrator (UPG-T) and receiver (UPE-T).

\section{Calcium alkoxides syntheses}

Synthesis and manipulation of calcium alkoxides were carried out in nitrogen filled glove-boxes with exclusion of moisture and oxygen. Solvents were purified by standard procedures; ${ }^{19}$ before use, calcium granules (Aldrich Chemical Company, 99\%) were cleaned in dry ethyl ether by vigorous stirring, which allows the removal of the oxide patina; other reagents were commercial products used as supplied.

$\left[\mathrm{Ca}\left(\mathrm{OCH}_{2} \mathrm{CH}_{3}\right)_{2}\left(\mathrm{CH}_{3} \mathrm{CH}_{2} \mathrm{OH}\right)_{4}\right](4),\left[\mathrm{Ca}\left(\mathrm{OCH}_{3}\right)_{2}\right](5)$ and [ $\left.\left\{\mathrm{Ca}\left(\mathrm{OCH}_{2} \mathrm{CH}_{2} \mathrm{OCH}_{3}\right)_{2}\right\}_{9}\right](\mathbf{6})$ were synthesised according to procedures described in the literature, ${ }^{1,20}$ their identity confirmed by comparison with literature data and fully supported by elemental analysis results. 
Syntheses of $\left[\mathrm{Ca}\left(\mathrm{O}\left(\mathrm{CH}_{2} \mathrm{CH}_{2} \mathrm{O}\right)_{3} \mathrm{CH}_{3}\right)_{2}\right](1)$, $\left[\mathrm{Ca}\left(\mathrm{O}\left(\mathrm{CH}_{2} \mathrm{CH}_{2} \mathrm{O}\right)_{3^{-}}\right.\right.$ $\left.\left.\mathrm{CH}_{2} \mathrm{CH}_{3}\right)_{2}\right]$ (2) and $\left[\mathrm{Ca}\left(\mathrm{OCH}_{2} \mathrm{C}\left(\mathrm{CH}_{3}\right)_{3}\right)_{2}\right]$ (3). Calcium granules (10 mmol) and the suitable alcohol (triethylene glycol monomethyl ether for (1), triethylene glycol monoethyl ether for (2) and 2, 2-dimethyl-1-propanol for (3)) (1.95 mmol) were added to toluene $(30 \mathrm{~mL})$. The mixture was refrigerated just above the solvent melting point and maintained at this temperature under stirring. $\mathrm{NH}_{3}$ was bubbled into the mixture at intervals. Reaction took place with formation of tiny bubbles evolution on the calcium surface, which turned golden yellow, until total consumption of calcium granules $(48 \mathrm{~h})$. The mixture was filtered and the solvent evaporated under vacuum to give:

(1) An amber-coloured viscous oil which was analysed and identified as $\left[\mathrm{Ca}\left(\mathrm{O}\left(\mathrm{CH}_{2} \mathrm{CH}_{2} \mathrm{O}\right)_{3} \mathrm{CH}_{3}\right)_{2}\right]$ (found: $\mathrm{C} 45.98, \mathrm{H}$ $8.09 \%$; calcd. for $\mathrm{C}_{14} \mathrm{H}_{30} \mathrm{O}_{8} \mathrm{Ca}$ : C 45.90, $\mathrm{H} 8.20 \%$; 84\% yield).

${ }^{1} \mathrm{H}$ NMR: $\mathrm{C}_{6} \mathrm{D}_{6}, \delta$, ppm: $3.20\left(\mathrm{~s}, 6 \mathrm{H}, \mathrm{OC}_{3}\right), 3.44$ (tb, $4 \mathrm{H}$, $\left.\mathrm{CH}_{2} \mathrm{OCH}_{3}\right), 3.61$ (sb, 4H, $\left.\mathrm{CH}_{2} \mathrm{O}\right), 3.68-4.10(\mathrm{mb}, 12 \mathrm{H}$, $\mathrm{CH}_{2} \mathrm{O}$ ), 4.37 (sb, $\left.4 \mathrm{H}, \mathrm{CH}_{2} \mathrm{CH}_{2} \mathrm{OCa}\right)$.

IR (cm $\left.{ }^{-1}\right): 2924 \mathrm{~m}, 2873 \mathrm{~m} \mathrm{(sh),} 2815 \mathrm{~m}, 1454 \mathrm{w}, 1351 \mathrm{w}$, $1301 \mathrm{w}, 1247 \mathrm{w}, 1200 \mathrm{w}, 1107 \mathrm{~s}, 1030 \mathrm{~m}, 935 \mathrm{w}, 884$ w, 852 w, $732 \mathrm{w}, 696 \mathrm{w}$.

(2) An amber-coloured viscous oil which was analysed and identified as $\left[\mathrm{Ca}\left(\mathrm{O}\left(\mathrm{CH}_{2} \mathrm{CH}_{2} \mathrm{O}\right)_{3} \mathrm{CH}_{2} \mathrm{CH}_{3}\right)_{2}\right]$ (found: $\mathrm{C} 49.69$, $\mathrm{H} 8.77 \%$; calcd. for $\mathrm{C}_{16} \mathrm{H}_{34} \mathrm{O}_{8} \mathrm{Ca}$ : $\mathrm{C} 48.73, \mathrm{H} 8.63 ; 88 \%$ yield).

${ }^{1} \mathrm{H}$ NMR: $\mathrm{d}_{8}$-toluene, $\delta$ ppm: $1.14\left(\operatorname{tr}, 6 \mathrm{H}, \mathrm{OCH}_{2} \mathrm{CH}_{3}\right), 3.37$ (q, $4 \mathrm{H}, \mathrm{OCH}_{2} \mathrm{CH}_{3}$ ), 3.49 (t, $4 \mathrm{H}, \mathrm{CH}_{2} \mathrm{OCH}_{2} \mathrm{CH}_{3}$ ), 3.60 (sb, $4 \mathrm{H}$, $\mathrm{CH}_{2} \mathrm{O}$ ), 3.69 (sb, $4 \mathrm{H}, \mathrm{CH}_{2} \mathrm{O}$ ), 3.77 (sb, 4H, $\left.\mathrm{CH}_{2} \mathrm{CH}_{2} \mathrm{OCa}\right) 3.81$ (sb, $4 \mathrm{H}, \mathrm{CH}_{2} \mathrm{O}$ ), 4.20 (sb, $\left.4 \mathrm{H}, \mathrm{CH}_{2} \mathrm{CH}_{2} \mathrm{OCa}\right)$.

${ }^{13} \mathrm{C} \mathrm{NMR} \mathrm{d}_{8}$-toluene, $\delta$ ppm: $15.6 \mathrm{ppm}\left(\mathrm{OCH}_{2} \mathrm{CH}_{3}\right), 63.5$ $\left(\mathrm{CH}_{2} \mathrm{CH}_{2} \mathrm{OCa}\right), 66.7\left(\mathrm{OCH}_{2} \mathrm{CH}_{3}\right), 70.5\left(\underline{\mathrm{CH}}_{2} \mathrm{OCH}_{2} \mathrm{CH}_{3}\right), 70.7$ $\left(\mathrm{CH}_{2} \mathrm{O}\right), 71.1\left(\mathrm{CH}_{2} \mathrm{O}\right), 76.8\left(\mathrm{CH}_{2} \mathrm{CH}_{2} \mathrm{OCa}\right)$.

IR $\left(\mathrm{cm}^{-1}\right): 2974 \mathrm{~m}, 2927 \mathrm{~m}(\mathrm{sh}), 2870 \mathrm{~s}, 1486 \mathrm{w}, 1455 \mathrm{w}$, 1397 w, 1379 w, 1349 w, 1305 w, 1248 w, 1108 s, 1073 m(sh), $945 \mathrm{w}, 885 \mathrm{w}, 844 \mathrm{w}, 700 \mathrm{w}, 668 \mathrm{w}$.

(3) A white powder which was analysed and identified as $\mathrm{Ca}\left(\mathrm{OCH}_{2} \mathrm{CMe}_{3}\right)_{2}$ (found: C 55.72, $\mathrm{H} 10.39 \%$; calcd. for $\mathrm{C}_{10} \mathrm{H}_{22} \mathrm{O}_{2} \mathrm{Ca}$ : C 56.07, $\mathrm{H} \mathrm{10.28;81 \%} \mathrm{yield).}$

${ }^{1} \mathrm{H}$ NMR: pyr-d ${ }_{5}, \delta$ ppm: $1.02\left(\mathrm{~s}, 9 \mathrm{H},\left(\mathrm{CH}_{3}\right)_{3} \mathrm{C}\right), 3.48(\mathrm{~s}, 2 \mathrm{H}$, $\left.\mathrm{CH}_{2} \mathrm{O}\right)$.

IR $\left(\mathrm{cm}^{-1}\right)$ : $2972 \mathrm{~s}, 2861 \mathrm{~m}, 2803 \mathrm{~m}, 1477 \mathrm{w}, 1457 \mathrm{w}, 1393 \mathrm{w}$, $1356 \mathrm{w}, 1095 \mathrm{~s}, 1020 \mathrm{~m}, 928 \mathrm{w}, 746 \mathrm{w}, 718 \mathrm{w}, 696 \mathrm{w}$.

\section{Preliminary studies of solution stability and alcoholic exchange}

We already reported the possible interchange reaction for calcium alkoxides in alcohols, ${ }^{1}$ with a complete formation of methoxide after $24 \mathrm{~h}$ of stirring the ethoxide in methanol. For this reason, (1), (2), (6) were dissolved in methyl alcohol $(\mathrm{MeOH})$, ethyl alcohol $(\mathrm{EtOH})$ and isopropyl alcohol $(i-\mathrm{PrOH})$ to evaluate the possible exchange reaction. All solvents were freshly distilled and the solution was maintained under an inert $\left(\mathrm{N}_{2}\right)$ atmosphere, to prevent hydrolytic processes.

In all cases the reaction with $\mathrm{MeOH}$ results in a suspension with the precipitation of $\left[\mathrm{Ca}(\mathrm{MeO})_{2}\right]$, the solution with $\mathrm{EtOH}$ remains clear for 2 days before the formation of a white precipitate $\left[\mathrm{Ca}(\mathrm{EtO})_{2}\right]$, while the solution in $i-\mathrm{PrOH}$ remains clear for at least 10 days.

${ }^{1} \mathrm{H}$ NMR spectra in benzene- $\mathrm{d}_{6}$ solution of the residue after the evaporation of the alcohol confirm the exchange reaction with $\mathrm{MeOH}$ and EtOH and the stability to $i$-PrOH alcoholysis. Whereas the spectrum of the $i$-propyl solution recorded after 10 days, still evidence the sole presence of the alkoxide, only the starting alcohol can be detected in the spectra of methanol and ethanol solutions.

No systematic investigation of the stability of alkoxides was performed: a detailed study is currently carried out within the European Project Nanomatch. ${ }^{17}$

\section{$\mathrm{CaCO}_{3}$ deposition from $\mathrm{Ca}$ alkoxides dispersed in alcohols}

Suitable quantities of compounds 1-4, 6 (corresponding to $2.5 \mathrm{~g} \mathrm{~L}^{-1}$ of $\mathrm{Ca}$ ) were added to isopropyl alcohol $(i-\mathrm{PrOH})$ $\left(5\right.$ was dissolved in methanol ${ }^{1}$ ) and the resulting solutions were placed in glassy vessels and exposed to the atmosphere for 20 days. The white coatings produced on the glass surface from reaction of the complexes with air were structurally analysed by XRD.

Methanol and water dispersion of 5 were also left in contact with air for 14 days, then the solid decomposition products dried, filtered and analysed. ${ }^{1}$

Glass frits generally used for chemical filtration (Bibby Scientific, diameter $30 \mathrm{~mm}$, thickness $3.5 \mathrm{~mm}$, porosity 4, experimentally calculated pores diameter 5-15 $\mu \mathrm{m}$ ) were chosen as porous substrates, simulating the disaggregated carbonate rocks, in order to study the behaviour of the calcium alkoxides in their transformation to calcium carbonate inside pores and cavities. This kind of porous substrate assures a defined range of pore sizes, allowing a reliable comparison of different series of experiments, difficult to perform in naturally occurring stone substrates due to their great variability in pore dimensions at the microscale. The frits were impregnated by same solutions of complexes 1-6, through imbibition: they were left in contact with the alkoxide solutions, which were drawn into the frits by capillarity, by three different applications (two hours each), performed at two days intervals. FEG-ESEM observation of the $\mathrm{CaCO}_{3}$ films deposited onto the frits was carried out.

Consolidation and impregnation studies of $\mathbf{5}$ have been previously reported. ${ }^{1}$

\section{Evaluation of consolidation effect}

Ultrasonic measurements were carried out on artificially aged Carrara marble specimens (dimension $5 \times 5 \times 1 \mathrm{~cm}$ ) before and after the application of alkoxides solution by imbibition. The samples were impregnated by contact imbibition with isopropyl alcohol solutions of complexes 1-6, prepared with a compound quantity equivalent to $6.25 \mathrm{~g} \mathrm{~L}^{-1} \mathrm{Ca}(\mathrm{OH})_{2}(2.5 \mathrm{~g}$ $\mathrm{L}^{-1}$ of $\mathrm{Ca}$ ), which was used by Baglioni et al. for $\mathrm{Ca}(\mathrm{OH})_{2}$ micro and nanoparticles dispersions in $i$-PrOH and tested for consolidation of carbonate stones. ${ }^{21,22}$ To compare the efficiency of the $\mathrm{Ca}$ alkoxides, a dispersion of $\mathrm{Ca}(\mathrm{OH})_{2}$ in $i$-PrOH (6.25 $\left.\mathrm{g} \mathrm{L}^{-1}\right)$ was applied and used as reference consolidant product.

Marble specimens set horizontally were soaked 3 times for 2 hours in alkoxides solutions, with the front side dipped by $2 \mathrm{~mm}$. The amount of the deposited compound after application was determined by weight difference (Fig. 4). 


\section{Acknowledgements}

Part of this work has been supported by the bilateral project GALILEO by both French and Italian Foreign Affairs Ministries, which are kindly acknowledged. The authors wish to thank Fila Industria Chimica Spa, San Martino di Lupari, Padova, Italy, owner of the Fei Quanta 200 FEG-ESEM instrument, for allowing its use for the research work described in this article. A. Moresco, C. Valerio and A. Aguiari are also acknowledged for the technical assistance.

\section{References}

1 M. Favaro, P. Tomasin, F. Ossola and P. A. Vigato, Appl. Organomet. Chem., 2008, 22, 698.

2 J. Ashurst, The cleaning and treatment of limestone by the lime method: part I, Monumentum, 1984, 3, 233.

3 M. Ambrosi, L. Dei, R. Giorgi, C. Neto and P. Baglioni, Langmuir, 2001, 17, 4251.

4 D. C. Bradley, R. C. Merhotra and D. P. Gaur, Metal Alkoxides, Academic Press, London, 1978.

5 D. C. Bradley, R. C. Mehrotra, I. P. Rothwell and A. Singh, Alkoxo and Aryloxo Derivatives of Metals, Academic Press, London, 2001.

6 N. Y. Turova, E. P. Turevskaya, V. G. Kessler and M. I. Yanovskaya, The Chemistry of Metal Alkoxides, Kluwer Academic Publishers, Dordrecht, 2002.
7 D. C. Bradley, Chem. Rev., 1989, 89, 1317.

8 U. Schubert and N. Husing, Synthesis of Inorganic Materials, Wiley-VCH, Weinheim, 2000.

9 S. R. Drake and D. J. Otway, J. Chem. Soc., Chem. Commun., 1991, 517.

10 R. Snethlage and K. Sterflinger, Stone Conservation, in Stone in Architecture, ed. S. Siegesmund and R. Snethlage, Springer-Verlag, Berlin Heidelberg, 2011, p. 411.

11 A. P. Ferreira Pinto and J. Delgado Rodrigues, J. Cult. Heritage, $2008,9,38$.

12 Final report of Galileo Project (2008/2009) "Materiali innovativi per il consolidamento della pietra calcarea e dei dipinti murali" Nouveaux matériaux consolidants pour pierre calcaire et peintures murales.

13 W. S. Rees Jr. and D. A. Moreno, J. Chem. Soc., Chem. Commun., 1991, 1759.

14 V. C. Arunasalam, I. Baxter, J. A. Darr, S. R. Drake, M. B. Hursthouse, K. M. A. Malik and D. M. P. Mingos, Polyhedron, 1998, 17, 641.

15 H. Cölfen, Curr. Opin. Coll. Int. Sci., 2003, 8, 23.

16 F. Manoli and E. Dalas, J. Cryst. Growth, 2000, 218, 359.

$17 \mathrm{http} / / /$ www.nanomatch-project.eu/nanomatch0.html.

18 C. R. Hubbard and R. L. Snyder, Powder Diffr., 1988, 3(2), 74.

19 D. D. Perrin, W. L. F. Armarego and D. R. Perrin, Purification of Laboratory Chemicals, Pergamon Press, Oxford, 1966.

20 S. C. Goel, M. A. Matchett, M. Y. Chiang and W. E. Buhro, J. Am. Chem. Soc., 1991, 113, 1844.

21 R. Giorgi, L. Dei and P. Baglioni, Stud. Conserv., 2000, 45, 154.

22 P. Baglioni and R. Giorgi, Soft Matter, 2006, 2, 293. 